\title{
KARAKTERISTIK PETANI DAN PROFIL USAHATANI UBI JALAR DI KECAMATAN ARJASARI, KABUPATEN BANDUNG
}

\author{
Hepi Hapsari ${ }^{1}$, Elly Rasmikayati ${ }^{1}$, Agung Karuniawan', dan Bobby Rachmat Saefudin ${ }^{2}$ \\ ${ }^{1}$ Fakultas Pertanian, Universitas Padjadjaran, Jl. Raya Bandung-Sumedang KM. 21 Jatinangor, Sumedang, 456363 \\ ${ }^{2}$ Fakultas Pertanian, Ma'soem University, J1. Raya Cipacing No. 22, Jatinangor, Sumedang, 40132 \\ E-mail: hepi.hapsari@unpad.ac.id
}

\begin{abstract}
ABSTRAK. Ubi jalar merupakan salah satu sumberdaya hayati unggulan yang berdaya saing industri karena permintaan untuk ekspor yang tinggi. Namun demikian, kajian agribisnis ubi jalar dari sudut pandang sosial ekonomi di tingkat petaninya belum banyak diteliti. Penelitian ini bertujuan untuk: 1) Menganalisis karakteristik individu petani ubi jalar; dan 2) Memahami karakteristik usahatani ubi jalar ditinjau dari penggunaan benih ubi jalar, status kepemilikan lahan, pola tanam ubi jalar, penggunaan pupuk dan pestisida serta hasil produksi dan sistem pemasaran ubi jalar.Penelitian ini berlokasi di Kec. Arjasari, Kab. Bandung. Metode penelitian menggunakan metodesurveydengan teknik Simple Random Sampling. Alat análisis data yang digunakan adalah descriptive statistics analysis yang diperkaya denganhasil Focus Discussion Group (FGD). Hasil penelitian didapatkan bahwa petani ubi jalar di Kec. Arjasari, rata-rata berusia 51 tahun dengan pekerjaan utamanya adalah bertani ubi jalar. Mayoritas petani ubi jalar memiliki tingkat pendidikan rendah (SD dan tidak tamat SD) dengan kepemilikan lahan seluas 0,11-0,5 Ha yang merupakan warisan turuntemurun. Petani menanam ubi jalar varietas kuningan putih (AC Putih) dan ubi ungu. Pemupukan biasanya hanya dilakukan sekali yaitu pada saat tanaman berusia sekitar 2 bulan dengan sistem pembukaan tanah. Rata-rata produksi ubi jalar petani adalah 250-300 $\mathrm{kg} / 100 \mathrm{~m}^{2}$. Tujuan pasar petani responden yakni bandar dengan sistem pembayaran tunai maupun tebasan. Kegiatan pascapanen seperti penyortiran dilakukan oleh petani dan bandar bersamaan saat berlangsungnya transaksi.
\end{abstract}

Kata kunci: karakteristik petani; usahatani; ubi jalar

\section{FARMERS CHARACTERISTICS AND FARM BUSINESS PROFILE OF SWEET POTATO IN ARJASARI DISTRICTS, BANDUNG REGENCY}

\begin{abstract}
Sweet potato is one of commodity that have industrial competitiveness due to high export demand. However, socioeconomic viewpoint at the level of the farmers of sweet potato agribusiness study have not been studied. The objectives of this paper, i.e. : 1) analyzing individual characteristics of sweet potato farmers; and 2) Understanding characteristics of sweet potato farming in terms of sweet potato seed use, land ownership status, sweet potato garden pattern, fertilizers and pesticides use and the production and marketing system of sweet potatoes. This study is located in the Arjasari District, Bandung Regency by using survey method with simple random sampling technique. Data is analyzed byusing descriptive statistics analysis and enriched by Focus Group Discussion (FGD) method. The results of the study showed that sweet potato farmers in the Arjasari has the average 51 years old with farmer as their main job. Majority farmers are very low level of education (primary and not completed primary school) with private land ownership measuring 0.11 to 0.5 hectares of mostly hereditary legacy. Farmers planting white brass (AC White) and purple varieties. Fertilization is usually done only once when the age of the plant stomping around 2 months. Average production isamounted to 250-300 kg/100 $\mathrm{m}^{2}$ of land. Their market destination is the Bandar with cash and slash payment systems. Postharvest activities such as sorting are carried out by farmers and dealers at the same time as the transaction.
\end{abstract}

Key words: farmers characteristic; sweet potato; farm business

\section{PENDAHULUAN}

Agribisnis merupakan pilihan pemerintah untuk dijadikan instrumen dalam menyejahterakan petani. Sebagai fakta bahwa agribisnis merupakan suatu sistem yang sangat kompleks yang menyangkut berbagai aspek dan saling terkait satu sama lain. Ubi jalar (Ipomoea batatas (L.) Lam.) merupakansalah satu sumberdaya nabati potensial dengan kandungan karbohidrat tinggi yang dapat mendukung terwujudnya ketahanan pangan nasional. Selain itu, ubi jalar juga mengandung mineral dan vitaminyang tinggi (Ishida et al., 2000; Manrique and Roca, 2007; Burri, 2011). Ubi jalar dapat dimanfaatkan sebagai alternatif bahan pangan maupun sebagai bahan baku industri seperti a) daun untuk sayuran dan pakan ternak, b) batang untuk bahan tanam dan pakan ternak, c) kulit ubi untuk pakan ternak, d) ubi segar digunakan sebagai bahan makanan, e) tepung ubi jalar sebagai bahan makanan, f) pati ubi jalar dimanfaatkan untuk fermentasi, pakan ternak, asam sitrat (Zuraida dan Supriati, 2001). Pemanfaatan ubi jalar sebagai bahan pangan, bahan baku industri, dan sumber energi merupakan respon terhadap kebijakan pemerintah tentang "Kebijakan Percepatan Penganekaragaman Konsumsi Pangan Berbasis Sumber Daya Lokal", menunjang visi misi Jawa Barat "meningkatkan ekonomi pertanian" dengan prioritas tematik sektoral/tema riset potensial yaitu Jawa Barat bebas rawan pangan,serta dilandasi topik riset pilar pangan Universitas Padjadjaran yaitu "pangan lokal untuk pangan nasional".। 
Berdasarkan data FAO dalam El Sheikhaet al. (2017) menunjukkan bahwa Indonesia merupakan produsen ubi jalar kelima di dunia dengan total produksi mencapai 4 juta ton.Permintaan pasar ekspor ubi jalar di Indonesia untuk bahan bakuubi madu, stick, dan pasteterus meningkat. Kebutuhan ekspor bahan baku ubi segar pada 2014 sekitar 15 ton/hari untuk ubi "madu", 20 ton/hari untuk bahan baku stick, dan 25 ton/hari untuk pasta. Selain itu pada 2016, Indonesia mampu mengeskpor ubi jalar segar sebanyak 9.540 ton dengan tingkat konsumsi 2,12$8,64 \mathrm{~kg}$ perkapita per tahun (Nugroho etal., 2017).Namun, dalam potensi tersebut terdapat beberapa permasalahan yang dihadapi oleh industri berbasis ubi jalar di Indonesia diantaranya adalah tidak terjaminnya kontinyuitas bahan baku ubi jalar dari produsen baik kuantitas maupun kualitasnya, dan potensi hasil yang masih rendah. Hal ini disebabkan berbagai faktor yang terkait dengan kegiatan usahatani ubi jalar, seperti masih rendahnya kapasitas produksi ubi jalar produsen (kuantitas dan kualitas), terbatasnya luas tanam, rendahnya pemahaman bisnis dari pelaku produsen ubijalar, dan masih rendahnya keterkaitan antara produsen ubi jalar sebagai penghasil bahan baku industri dengan mitra industri.

Wilayah sentra produksi ubi jalar di Indonesia adalah Provinsi Jawa Barat, Papua, Jawa Timur, NTT, dan Jawa Tengah (Rusdiana et.al., 2017). Provinsi Jawa Barat pada 2017 memiliki luas panen ubi jalar 22.479 Ha dengan produksi sebanyak 477.828 ton dan produktivitas 21,6 ton/ha (Kementerian Pertanian, 2018). Namun demikian, berdasarkan data dari Direktorat Jenderal Tanaman Pangan tahun 2013 produktivitas ubi jalar Jawa Barat tersebut masih rendah dibandingkan produktivitas potensial yang mampu dihasilkan yakni 25-30 ton/ha. Belum adanya arahan yang jelas terkait pengembangan ubi jalar menyebabkan petani melakukan uji tanam ubi jalar pada lahan yang belum tentu sesuai dengan SOP atau di lahan marginal. Perbedaan lingkungan tumbuh ubi jalar menyebabkan perkembangan dan hasil ubi baik secara kualitas maupun kuantitas dapat berbeda (Nedunchezhiyan et.al. 2012). Diketahui bahwa wilayah yang sesuai bagi pertumbuhan dan hasil ubi jalar dapat menunjang ekstensifikasi budidaya ubi jalar secara optimal. Terlebih dengan adanya varietas ubi jalar unggul yang berpeluang untuk digunakan secara luas. Hal ini dapat menunjang peningkatkan ketersediaan produksi baik dari segi kuantitas, kualitas, maupun kontinyuitas ubi jalar serta dapat mendukung pemenuhan pasokan bahan baku industri berbasis pangan ubi jalar.

Karakteristik petani selaku aktor yang berperan penting dalam kegiatan usaha tani mencerminkan perilaku yang menggambarkan motivasi, karakteristik pribadi (ciri khas), konsep diri, nilai-nilai, pengetahuan atau keahlian yang dibawa seorang petani yang berkinerja unggul dalam berusahatani. Keberhasilan usahatani sangat bergantung pada kompetensi petani sebagai pengelola utama. Kompetensi petani tidak sama satu dengan lainnya, hal ini sangat tergantung kepada karakteristik yang mereka miliki (Manyamsari dan Mujiburrahmad, 2014). Asmarantaka (2017) menyatakan bahwa karakteristik petani responden merupakan salah satu hal penting karena akan berhubungan langsung dengan kegiatan usahatani. Berdasarkan hasil penelitiannya diketahui rata-rata umur petani ubi jalar adalah 49 tahun, tingkat pendidikan pada Sekolah Dasar (SD), rata-rata pengalaman usahatani 29 tahun, jumlah anggota keluarga sebanyak 4 orang, mayoritas petani tidak tergabung ke dalam kelompok tani.

Tingkat adopsi petani akan varietas unggul ubi jalar di Indonesia sangat rendah dan didominasi beragam varietas lokal yang spesifik lokasi. Dengan banyaknya varietas lokal ini maka kemungkinan variasi produktivitas ubi jalar di Indonesia berbasis masyarakat melalui penanaman varietas lokal yang beragam sangatlah besar. Beberapa varietas ubi jalar memiliki daya saing industri yang baik dan mudah untuk dibudidayakan oleh petani. Namun, kajian agribisnis ubi jalar dari sudut pandang sosial ekonomi di tingkat petaninya belum banyak diteliti. Dengan demikian, penelitian ini bertujuan untuk: 1) Menganalisis karakteristik individu petani ubi jalar; dan 2) Memahami karakteristik usahatani ubi jalar ditinjau dari penggunaan benih ubi jalar, status kepemilikan lahan, pola tanam ubi jalar, penggunaan pupuk dan pestisida serta hasil produksi dan sistem pemasaran ubi jalar.

\section{METODE}

Penelitian dilakukan dengan metode surveyeksplanatory, dengan teknik pengambilan sampel acak sederhana. Populasi penelitian adalah para petani ubi jalar di daerah sentra ubi jalar di Jawa Barat. Pengambilan sampel dilakukan dalam beberapa tahapan klaster. Tahap pertama, klaster sentra ubi jalar unggulan Unpad di Jawa Barat adalah Kecamatan Arjasari, Kabupaten Bandung. Dari Kecamatan Arjasari akan ditentukan sampel desa dengan rumus sampling acak klaster tahap pertama. Berdasarkan perhitungan menggunakan rumus sampel acak sederhana bisa diambil minimal 1 desa sentra ubi jalar unggulan Unpad yaitu Desa Arjasari. Penentuan Desa Arjasari sebagai lokasi penelitian dilakukan secara acak dengan menggunakan software minitab.

Selanjutnya dari Desa Arjasari diambil sejumlah responden petani ubi jalar dengan rumus sampling acak sederhana. Untuk menentukan ukuran sampel (sample size) yang akan digunakan sebagai sumber informasi dalam penelitian ini digunakan teknik penarikan sampel acak sederhana sebagai berikut (Anderson et. al.): 
dimana:

$n=\frac{N \bar{p}(1-\bar{p})}{\left(\frac{B^{2}}{4 N}\right)+\bar{p}(1-\bar{p})}$

$n=$ ukuran sampel

$N=$ ukuran populasi

$\bar{p}=$ point estimate untuk proporsi populasi dengan sampling error terkecil $=0,5$

$n=$ bound on sampling error $=2 \times 0,005 \times N=0,1 \times N$

Dengan tidak adanya data valid tentang jumlah petani ubi jalar di Kecamatan Arjasari maka digunakan ukuran sampel sebanyak 100 orang petani. 100 orang petani ubi jalar tersebutlah yang dijadikan sebagai responden pada penelitian terkait petani ubi jalar unggulan Unpad. Ukuran sampel tersebut dapat menutupi dan mewakilkan ukuran populasi petani ubi jalar yang tak terhingga. Data diolah menggunakan alat analisis statistika deskriptif seperti diagram pie, tabel distribusi frekuensi, dan crosstabulation.

\section{Analisis Pendapatan dan R/C Ratio}

Pendapatan usahatani adalah selisih antara penerimaan dan biaya yang dikeluarkan. Biaya dalam usahatani terdiri dari biaya tunai dan biaya tidak tunai (biaya diperhitungkan). Tingkat penerimaan total usahatani dirumuskan sebagai berikut (Soekartawi, 1995) :

$$
\mathbf{T R}=\mathbf{P}_{\mathbf{y}} \mathbf{x} \mathbf{Y}
$$$$
\begin{array}{ll}
\mathrm{TR} & =\text { Total penerimaan } \\
\mathrm{P}_{\mathrm{y}} & =\text { Harga per satuan produksi } \\
\mathrm{Y} & =\text { Jumlah Produksi }
\end{array}
$$

Pendapatan total usahatani dapat dinyatakan dalam persamaan:

$$
\begin{aligned}
& I_{\text {tunai }}=\mathbf{T R}-\mathbf{T C}_{\text {tunai }} \\
& \mathbf{I}_{\text {total }}=\mathbf{T R}-\left(\mathbf{T C}_{\text {tunai }}+\mathbf{B D}\right)
\end{aligned}
$$

Keterangan :

$$
\begin{array}{ll}
\mathrm{TR} & =\text { Penerimaan usahatani (Rp) } \\
\mathrm{P}_{\mathrm{y}} & =\text { Harga output }(\mathrm{Rp}) \\
\mathrm{Y} & =\text { Jumlah output }(\mathrm{Rp}) \\
\mathrm{I}_{\text {tunai }} & =\text { Pendapatan tunai }(\mathrm{Rp}) \\
\mathrm{I}_{\text {total }} & =\text { Pendapatan total }(\mathrm{Rp}) \\
\mathrm{TC}_{\text {tunai }} & =\text { Total biaya tunai }(\mathrm{Rp}) \\
\mathrm{BD} & =\text { Biaya diperhitungkan }(\mathrm{Rp})
\end{array}
$$

Analisis $\mathrm{R} / \mathrm{C}$ rasio digunakan untuk mengetahui seberapa besar penerimaan yang dihasilkan dari setiap rupiah yang dikeluaran untuk biaya usahatani. $\mathrm{R}=$ revenue (penerimaan); $\mathrm{C}=$ cost (biaya total). Jika nilai $\mathrm{R} / \mathrm{C}>1$, berarti usahatani layak untuk dilakukan. Sebaliknya jika nilai $\mathrm{R} / \mathrm{C}<1$, berarti usahatani tersebut tidak layak untuk dilakukan.

\section{HASIL DAN PEMBAHASAN}

\section{Karakteristik Petani Ubi Jalar di Kecamatan Arjasari Karakteristik Responden Berdasarkan Usia}

Usia petani merupakan faktor yang paling erat kaitannya dengan kekuatan dan kemampuan petani dalam melakukan kegiatan usahatani. Berdasarkan Tabel 1 diketahui bahwa usia mayoritas petani ubi jalar di Keca-matan Arjasari berada pada kisaran 41-60 tahun dengan rata-rata usia 51 tahun. Dengan berpatokan pada usia produktif manusia bekerja yakni 15-64 tahun maka rata-rata usia petani tersebut termasuk ke dalam petani tua produktif. Petani yang berumur lebih tua biasanya kurang responsif terhadap perubahan inovasi teknologi (Asmarantaka, 2017).

Tabel 1. Karakteristik Responden Berdasarkan Usia

\begin{tabular}{cccc}
\hline No & Usia & $\begin{array}{c}\text { Frekuensi / } \\
\text { Persentase (\%) }\end{array}$ & Rata-rata Usia \\
\hline 1 & $\leq 30$ tahun & 6 & \\
2 & $31-40$ tahun & 29 & 51 tahun \\
3 & $41-60$ tahun & 55 & \\
4 & $\geq 61$ tahun & 21 & \\
\hline & Total & $\mathbf{1 0 0}$
\end{tabular}

Sumber: Data Primer 2018

Petani ubi jalar dengan usia dibawah atau sama dengan 30 tahun memiliki persentase paling rendah diantara kategori usia lainnya, padahal usia tersebut adalah usia dimana seseorang memiliki kekuatan bekerja yang sangat baik. Hal ini dapat menunjukkan bahwa sangat terbatasnya golongan muda yang bersedia bekerja di sektor pertanian terutama usahatani ubi jalar. Sektor industri yang saat ini berkembang pesat dengan jaminan memperoleh pendapatan yang lebih tinggi menjadi alasan kuat pengalihan minat kaum muda untuk bekerja di sektor pertanian.

\section{Karakteristik Responden Berdasarkan Pekerjaan Utama dan Pekerjaan Sampingan}

Pada Tabel 2 terlihat bahwa 80\% dari total petani responden yang dijadikan sampel penelitian menjadikan usahatani ubi jalar sebagai pekerjaan utamanya. Ini menunjukkan bahwa kegiatan usahatani ubi jalar merupakan pekerjaan yang menjadi primadona bagi masyarakat di Kecamatan Arjasari, Kabupaten Bandung. Sedangkan dari tabel juga diketahui bahwa kurang dari 30\% responden menjadikan usahatani ubi jalar sebagai pekerjaan sampingannya. 
Tabel 2. Karakteristik Responden Berdasarkan Pekerjaan Utama dan Pekerjaan Sampingan

\begin{tabular}{clclc}
\hline No & $\begin{array}{c}\text { Pekerjaan } \\
\text { Utama }\end{array}$ & $\begin{array}{c}\text { Frekuensi/ } \\
\text { Persentase } \\
(\%)\end{array}$ & $\begin{array}{l}\text { Pekerjaan } \\
\text { Sampingan }\end{array}$ & $\begin{array}{c}\text { Frekuensi } / \\
\text { Persentase } \\
\mathbf{( \% )}\end{array}$ \\
\hline 1 & Pedagang & 4 & Pedagang & 4 \\
2 & $\begin{array}{l}\text { Petani Ubi } \\
\text { jalar }\end{array}$ & 87 & $\begin{array}{l}\text { Petani Ubi } \\
\text { jalar }\end{array}$ & 17 \\
3 & PNS & 3 & PNS & 1 \\
4 & Lainnya & 6 & Lainnya & 45 \\
\hline & Total & 100 & Total & 67 \\
\hline
\end{tabular}

Sumber: Data Primer 2018

Mayoritas petani responden memiliki pekerjaan sampingan yang cukup beragam diantaranya adalah guru, buruh, supir, petani padi dan palawija, petani jambu, petani pisang, dan lain-lain, sedangkan 33 orang petani responden tidak memiliki pekerjaan sampingan atau dapat dikatakan hanya menjadikan petani ubi jalar sebagai satu-satunya profesi/pekerjaan yang ditekuni. Hal ini kemudian menjadi menarik karena kurang lebih $1 / 3$ dari total responden petani ubi jalar menjadikan usahatani ubi jalar sebagai pekerjaan utama dan satu-satunya pekerjaan untuk memenuhikebutuhan keluarganya. Ini dapat membuktikan bahwa usahatani ubi jalar adalah usahatani yang menguntungkan dan menjanjikan untuk dilakukan.

\section{Karakteristik Responden Berdasarkan Tingkat Pendidikan Terakhir}

Mengacu pada Tabel 3 diketahui bahwa mayoritas petani ubi jalar di Kecamatan Arjasari berpendidikan terakhir SD (Sekolah Dasar). Menurut Shead dalam Rachmat (2016), tingkat pendidikan dapat diklasifikasikan menjadi tiga, yaitu: (1) tingkat pendidikan rendah: buta huruf-SD; (2) tingkat pendidikan sedang: tamat SDtamat SMA; dan (3) tingkat pendidikan tinggi: tamatAkademi/Perguruan Tinggi. Lionberger dalam Rachmat (2016) menegaskan bahwa tingkat pendidikan formal akan berpengaruh terhadap produktivitas usahatani, tingkat melek huruf, dan akses informasi, serta tingkat penyerapannya atas aplikasi dan alih teknologi yang akan berdampak terhadap partisipasi dan daya adopsinya.

Apabila pernyataan Lionberger dan Shead tersebut dikaitkan dengan tingkat pendidikan petani ubi jalar di Kecamatan Arjasari maka petani ubi jalar tersebut masuk ke dalam kategori petani dengan tingkat pendidikan rendah sehingga lebih sulit mencerna informasi dan adopsi inovasi mengenai teknologi dan pelaksanaan kegiatan usahatani ubi jalar yang lebih baik. Adapun penyebab banyaknya responden dengan tingkat pendidikan hanya sebatas Sekolah Dasar (SD) tersebutdipengaruhi oleh masih kurangnya perhatian terhadap pendidikan dan keterbatasan biaya untuk melanjutkan pendidikan ke jenjang yang lebih tinggi.

Tabel 3. Karakteristik Responden Berdasarkan Pendidikan Terakhir

\begin{tabular}{rlc}
\hline No. & Pendidikan Terakhir & $\begin{array}{c}\text { Frekuensi / Persentase } \\
\mathbf{( \% )}\end{array}$ \\
\hline 1 & Akademi/Diploma & 2 \\
2 & Sarjana & 3 \\
3 & SD & 55 \\
4 & SMA & 18 \\
5 & SMP & 18 \\
6 & Tidak Sekolah & 4 \\
\hline Total & & 100 \\
\hline
\end{tabular}

Sumber : Data primer 2018

\section{Karakteristik Responden Berdasarkan Pengalaman Usahatani Ubi jalar}

Tabel 4 menunjukkan bahwa mayoritas responden petani ubi jalar di Kecamatan Arjasari merupakan petani yang kurang berpengalaman/baru (kurang dari 15 tahun) dalam berusahatani ubi jalar. Awalnya, ubi jalar belum menjadi komoditas utama yang diusahakan, petani lebih cenderung bertani padi/palawija. Namun, sekitar tahun 2000, budidaya dan usahatani ubi jalar mulai gencar digalakan sehingga banyak petani beralih dari budidaya padi/palawija menjadi budidaya ubi jalar. Hal ini juga dibuktikan oleh banyaknya lahan sawah milik petani responden yang diubah fungsi menjadi kebun ubi jalar. Selain itu, banyak dari petani yang mendapatkan warisan berupa lahan/pohon ubi jalar sehingga mereka meneruskan usahatani ubi jalar hingga saat ini.

Tabel 4. Karakteristik Responden Berdasarkan Pengalaman Usahatani

\begin{tabular}{clc}
\hline No. & \multicolumn{1}{c}{$\begin{array}{c}\text { Pengalaman Usahatani } \\
\text { (Tahun) }\end{array}$} & $\begin{array}{c}\text { Frekuensi / Persentase } \\
\mathbf{( \% )}\end{array}$ \\
\hline 1 & $5-15$ & 53 \\
2 & $16-30$ & 32 \\
3 & $30-50$ & 13 \\
4 & $>50$ & 2 \\
\hline Total & & 100 \\
\hline
\end{tabular}

Sumber: Data Primer 2018

Petani dengan pengalaman usahatani ubi jalar kurang dari 5 tahun memiliki lahan ubi jalar yang sangat sempit dengan kondisi pohon yang belum produktif. Untuk meningkatkan penguasaan lahan dan jumlah pohon ubi jalarnya, petani tersebut cenderung melakukan sewa 
kepada pemilik pohon ubi jalar yang sudah produktif. Sedangkan, responden petani ubi jalar yang sudah berusa hatani ubi jalar selama lebih dari 50 tahun pada umumnya merupakan petani yang sudah memiliki lahan/pohon ubi jalar pribadi dan cenderung tidak menyewa lahan/pohon ubi jalar orang lain. Rata-rata pengalaman usahatani ubi jalar petani responden adalah 18 tahun dengan pengetahuan dan pemahaman terkait teknik budidaya ubi jalar diperoleh secara otodidak.

\section{Karakteristik Responden Berdasarkan Status Kepe- milikan dan Penguasaan Lahan Ubi Jalar}

Status penguasaan lahan petani ubi jalar dalam penelitian ini dibagi menjadi 3 kategori yaitu status penguasaan lahan ubi jalar milik pribadi, garap, dan sewa. Dapat dilihat pada Gambar 1.

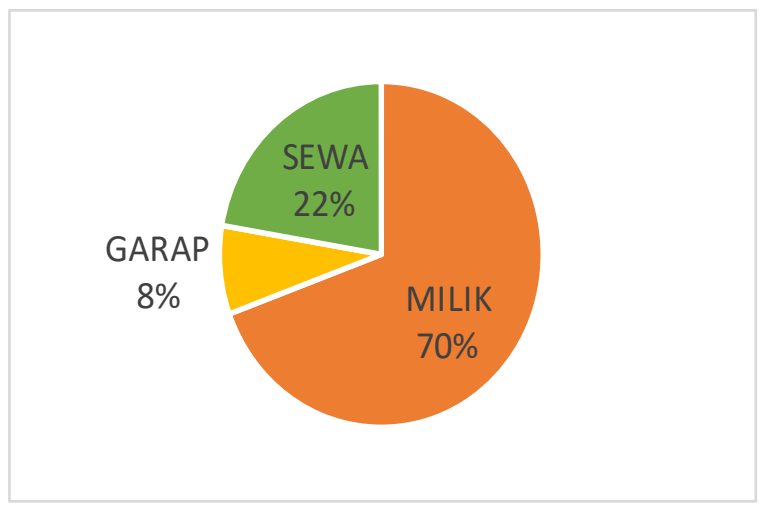

Gambar 1. Status Penguasaan Lahan Petani Ubi Jalar

Dari hasil penelitian di lapangan diketahui bahwa mayoritas petani ubi jalar memiliki lahan ubi jalar milik pribadi dengan kategori lahan sempit yakni 0,11-0,5 Ha dan tidak memiliki kebun/lahan ubi jalar lain yang digarap ataupun disewa. Kebun/lahan ubi jalar milik pribadi tersebut diperoleh petani respondendari warisan/harta peninggalan orangtua. Selain itu, terjadinya alih fungsi lahan oleh petani dari lahan sawah menjadi kebun/lahan ubi jalar yang mereka miliki menyebabkan penguasaan lahan ubi jalar tersebut secara otomatis berstatus milik.

Meskipun demikian, terdapat sebagian petani yang memiliki kebun/lahan ubi jalar dengan status milik dan juga sewa atau garap kebun/lahan ubi jalar milik orang lain. Sistem kontrak/sewa tersebut terkait dengan penyewaan pohon ubi jalar produktif milik petani lain, bukan satuan lahan. Jumlah pohon ubi jalar yang disewa oleh petani responden tersebut dikonversi ke dalam satuan luas lahan dan dibayar sesuai dengan kesepakatan. Status penguasaan lahan ubi jalar dan status penguasaan pohon ubi jalar memiliki hubungan yang bergaris lurus (linier). Rata-rata petani memiliki pohon ubi jalar pribadi sebanyak 11-50 pohon yang ditanam dengan jarak tanam pada umumnya yaitu $10 \times 10 \mathrm{~m}$, maka jika dikonversi ke luas lahan menjadi $0,11-0,5 \mathrm{Ha}$.

\section{Profil Usahatani Ubi Jalar Penggunaan Benih Ubi Jalar}

Petani ubi jalar di Kecamatan Arjasari yang dijadikan responden adalah petani yang menanam ubi jalar varietas kuningan putih (AC Putih) dan varietas ubi ungu. Varietas kuningan putih merupakan varietas lokal dan paling banyak dibudidayakan oleh petani di lokasi penelitian. Alasan petani menggunakan varietas kuningan putih dikarenakan varietas lokal unggulan dengan produktivitas tinggi, bercita rasa manis, bentuknya bulat, tahan terhadap panas, harga jual cukup tinggi, serta permintaan pasar yang kontinyu sepanjang tahun. Ciri fisik tanaman ubi jalar ini adalah daunnya yang runcing dan agak tipis serta berwarna hijau tua. Sedangkan varietas ubi ungu memiliki ciri fisik daunnya lebar dan tumbuh lebat serta warna daun yang hijau agak keunguan.

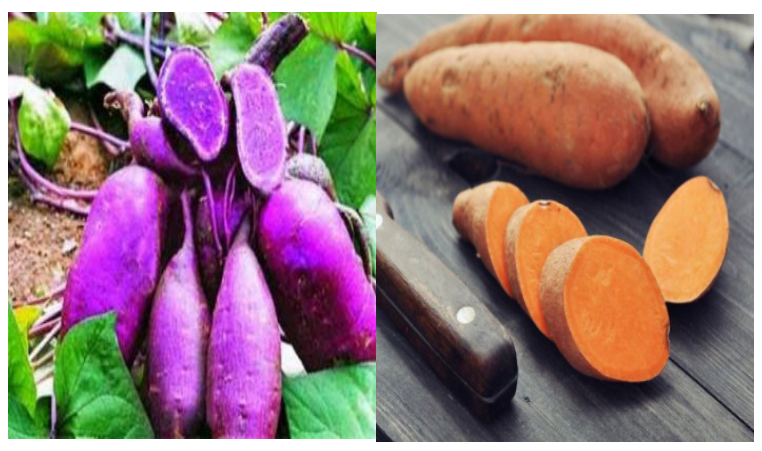

Gambar 2. Ubi Jalar Ungu (kiri) dan Ubi Jalar Kuning (kanan) yang banyak dibudidayakan oleh petani di Kecamatan Arjasari

\section{Status Lahan dan Pola Tanam Ubi Jalar}

Petani ubi jalar di Kecamatan Arjasari umumnya menanam ubi jalar di lahan milik pribadi. Pola tanam ubi jalar yang digunakan yakni pola tanamubi-palawija/padiubi yakni pola tanam yang diselingi penanaman palawija untuk lahan kebun/ladang dan padi untuk lahan sawah. Tanaman penyelang palawija dapat digantidengan tanaman kacang-kacangan untuk meningkatkan kesuburan tanah. Petani yang tidak memiliki lahan biasanya menyewa atau menyakap lahan milik orang lain. Sewa lahan atau pohon ubi jalar dibayar dengan menggunakan hasil panen ubi. Selain itu, ada juga petani yang menggarap lahan gadai untuk ditanami ubi jalar.

\section{Penggunaan Pupuk dan Pestisida}

Pemeliharaan tanaman ubi jalar memerlukan perhatian yang serius dan cukup intensif dalam pemeliharaan sehari-harinya. Berdasarkan Tabel 5 menunjukkan bahwa frekuensi pemupukan tanaman ubi jalar yang dilakukan oleh mayoritas responden petani ubi jalar adalah hanya 1 kali dalam 1 tahun. Hal ini dirasa cukup bagi petani karena dosis yang diberikan sudah dirasa cukup untuk kebutuhan setiap tanaman ubi jalar, selain itu pengerjaan pemupukan yang pada umumnya tidak cukup dilakukan 
dalam satu hari sehingga dapat menghemat waktu, tenaga, dan biaya jika hanya dilakukan sekali dalam setahun.

Kemudian berdasarkan tabel 6 menunjukkan bahwa penyiangan kebun ubi jalar yang dilakukan oleh mayoritas responden petani ubi jalar adalah hanya 1 kali dalam 1 tahun. Hal tersebut juga dirasa cukup oleh mayoritas petani ubi jalar, karena apabila dilakukan terlalu berlebihan kegiatan penyiangan dapat mengganggu pertumbuhan akar tanaman ubi jalar karena mayoritas petani ubi jalar bukan menggunakan alat manual dalam penyiangannya namun menggunakan obat pembasmi rumput liar/gulma.

Tabel 5. Frekuensi Pemupukan Pohon Ubi jalar/Tahun

\begin{tabular}{crc}
\hline No. & Pemupukan/Tahun & Frekuensi (Orang) \\
\hline 1 & 0 kali & 1 \\
2 & $1 \mathrm{kali}$ & 76 \\
3 & $2 \mathrm{kali}$ & 18 \\
4 & $3 \mathrm{kali}$ & 3 \\
5 & $4 \mathrm{kali}$ & 2 \\
\hline & & Total
\end{tabular}

Sumber: Data Primer 2018

Menurut ketua kelompok tani ubi jalar di Kecamatan Arjasari, pemupukan biasanya hanya dilakukan sekali saja yaitu pada saat tanaman berusia sekitar 2 bulan dengan sistem pembukaan tanah. Tanah dibuka agar akar ubi jalar terlihat kemudian diberikan pupuk (biasanya pupuk NPK) lalu ditutup kembali dengan tanah,tetapi tidak terlalu dalam. Hal ini dimaksudkan agar akar dapat bernafas dengan lebih baik dan air hujan/irigasi bisa langsung mengenai akar tanaman sehingga proses pertumbuhan umbi akan lebih maksimal. Untuk lahan kebun atau ladang, pemupukan dilakukan saat akan memasuki musim hujan. Hal ini dikarenakan jenis pupuk NPK yang digunakan petani akan bekerja secara optimal dan mudah terserap tanaman saat terkena air.

Tabel 6 menunjukkan bahwa frekuensi pemberian pupuk hayati tanaman ubi jalar yang dilakukan oleh mayoritas responden petani ubi jalar adalah hanya 1 kali dalam 1 musim. Hal tersebut dirasa sangat cukup dan memang sesuai dengan standar operasional budidaya ubi jalar teknologi nutrisi ramah lingkungan berbasis pupuk hayati. Pemberian pupuk hayati akan meningkatkan keseimbangan mikrobiologis sehingga dapat memperbaiki struktur tanah dan meningkatkan produksi ubi jalar.

Pemeliharaan tanaman ubi jalar yang berkala yaitu penyemprotan pestisida, fungisida, insektisida (obatobatan) dan penggunaan pupuk hayati. Jika rata-rata dalam satu tahun petani ubi jalar dapat memanen ubi jalarnya sebanyak 2-3 kali, maka terdapat 2-3 kali musim penyemprotan ini. Pada fase ini, frekuensi penyemprotan harus dilakukan secara rutin. Dari hasil penelitian di lapangan seperti yang dapat dilihat pada tabel 5.19 mayoritas responden petani ubi jalar melakukan penyemprotan pestisida dan obat penahan rontok bunga sebanyak 2 kali dalam 1 minggu. Penyemprotan ini biasanya dilakukan bersamaan dengan langsung mencampurkan bahan menjadi satu. Namun dalam beberapa kondisi dapat dilakukan tambahan dari salah satu zat tergantung cuaca di lapangan.

Tabel 6. Frekuensi Pemberian Pupuk Hayati pada Pohon Ubi jalar/Tahun

\begin{tabular}{|c|c|c|}
\hline No. & $\begin{array}{c}\text { Pemberian Pupuk Hayati/ } \\
\text { Musim }\end{array}$ & Frekuensi (Orang) \\
\hline 1 & 0 kali & 3 \\
\hline 2 & 1 kali & 87 \\
\hline 3 & 2 kali & 9 \\
\hline 4 & 3 kali & 1 \\
\hline Total & & 100 \\
\hline
\end{tabular}

Sumber: Data Primer 2018

Tabel 7. Frekuensi Penyemprotan Pestisida dan Pemeliharaan Bunga Ubi jalar

\begin{tabular}{ccc}
\hline No. & Penyemprotan/Minggu & Frekuensi (Orang) \\
\hline 1 & $1 \mathrm{kali} /$ minggu & 28 \\
2 & $2 \mathrm{kali} /$ minggu & 66 \\
3 & $3 \mathrm{kali} /$ minggu & 6 \\
\hline Total & & 100 \\
\hline
\end{tabular}

Sumber: Data Primer 2018

Namun ternyata, jumlah penyemprotan yang dilakukan mayoritas petani ubi jalar di lapangan tidak sesuai dengan standar operasional budidaya ubi jalar dengan teknologi nutrisi ramah lingkungan berbasis pupuk hayati. Hasil wawancara menunjukkan bahwa petani banyak atau sering melakukan penyemprotan dikarenakan khawatir ubi jalar akan terserang hama lanas jika sering terjadi hujan. Hal ini karena apabila ubi jalar terserang hama, maka petani tidak akan mendapatkan hasil umbi ubi jalar sehingga akan merugi. Meski begitu, penyemprotan yang berlebihan malah akan membuat tanaman ubi jalar menjadi rentan dan pengeluaran petani pun bertambah.

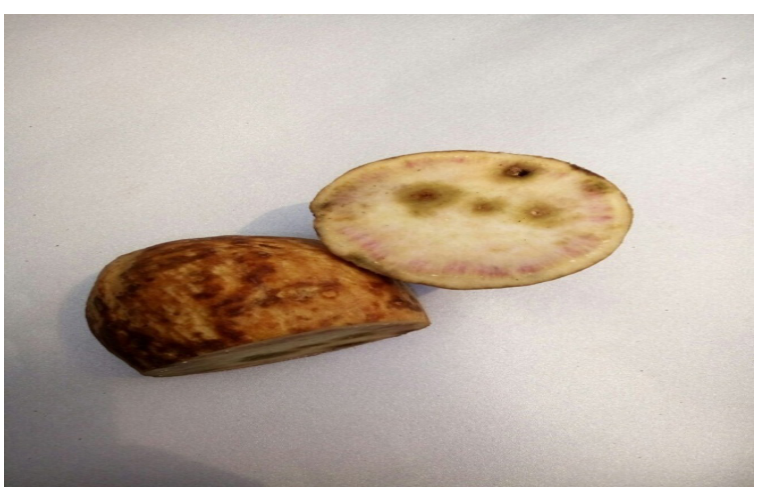

Gambar 3. Tampilan Ubi Jalar yang terkena hama "Lanas" 
Serangan hama "lanas" ini menyebabkan umbi manjadi busuk, permukaan kulit luar umbi tidak mulus, dan menimbulkan bau yang tidak sedap. Berdasarkan informasi dari beberapa petani, disebutkan bahwa jika ubi yang terkena hama tersebut diproses/dimasak maka akan terbentuk sejenis zat racun yang dapat meyebabkan gangguan kesehatan. Untuk meminimalisir dampak dari serangan hama tersebut, petani biasanya melakukan treatment khusus pada lahannya yakni dengan menambah kankapur dolomit dan garam tanpa iodium sebelum dilakukan penanaman atau pada saat pengolahan lahan. Hal ini bertujuan agar benih/larva "lanas" mati dan mencegah induknya untuk menyimpan lagi telur di lahan petani. Penyemprotan insektisida juga dilakukan untuk mengatasi serangan hama pengganggu tanaman ubi jalar. Meskipun petani sudah melakukan kegiatan pengendalian hama terhadap tanaman ubi jalarnya, namun faktanya masih terdapat kurang dari 50\% hasil panen ubi jalar yang terkena hama "lanas" tersebut

\section{Produksi dan Sistem Pemasaran Ubi Jalar}

Usahatani ubi jalar yang dibudidayakan petani responden di Kecamatan Arjasari mampu menghasilkan produksi sebanyak $250-300 \mathrm{~kg} / 100 \mathrm{~m}^{2}$. Tujuan pasar petani ubi jalar tersebut yakni bandar yang berada di sekitar lokasi tempat tinggal atau kebun ubi jalar. Hasil panen ubi jalar dijual langsung oleh petani kepada bandar dengan sistem pembayaran tunai/cash.Selain itu, terdapat petani yang menjual ubi jalar dengan sistem tebasan, yang mana kegiatan panen dilakukan oleh pembeli/bandar. Sistem tebasan ini dipilih petani karena lebih efisienyakni petani tidak perlu mengeluarkan biaya untuk upah tenaga kerja saat panen. Penyortiran ubi jalar biasanya dilakukan oleh petani dan bandar bersamaan pada saat kegiatan jualbeli berlangsung.

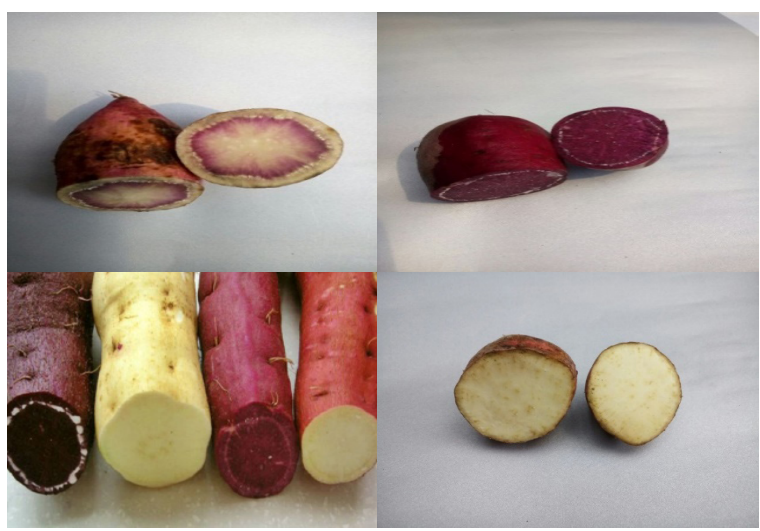

Gambar 4. Beberapa Hasil Panen Ubi Jalar di Lokasi Penelitian

Mayoritas responden petani ubi jalar yang memiliki tingkat pendidikan terakhir SD ternyata mereka memilih menjual hasil ubi jalarnya ke pedagang pengumpul/tengkulak. Sedangkan yang memasok ke pasar modern dan ke pasar tradisional secara langsung adalah responden petani yang tingkat pendidikannya lebih tinggi antara SMP dan SMA. Meski begitu, cukup banyak pula petani yang tingkat pendidikannya SMP dan SMA tetapi tetap memasok hasil ubi jalarnya ke pedagang pengumpul/ tengkulak. Ini berarti tingkat pendidikan petani tidak terlalu mempengaruhi petani untuk memasok hasil ubi jalarnya ke pasar tertentu.

Pada kegiatan pemasaran hasil panen ubi jalar, ternyata mayoritas petani sejak dulu awal memulai usahatani ubi jalar sudah memasok ke tujuan pemasaran yang sama dengan yang dilakukan pada saat ini. Tidak banyak yang berubah dari tujuan pemasaran petani ubi jalar. Adapun beberapa petani yang tadinya hanya memasok ke tengkulak/bandar kemudian mencoba menjual hasil ubi jalarnya ke pasar tradisional nyatanya lebih memilih menjual hasil ubi jalarnya ke tengkulak/bandar kembali. Pada umumnya lama waktu petani mencoba ke tujuan pasar yang baru tidaklah lebih dari 1 tahun.

Tujuan pasar petani ubi jalar yang mayoritas menjual hasil panen ubi jalarnya ke pedagang pengumpul/ tengkulak dan bandar ternyata kerap kali membuat petani tidak memiliki bargaining position yang tinggi di dalam penentuan harga jual umbi ubi jalar. Terlebih lagi apabila adanya bantuan sarpotan seperti berupa zat perangsang tumbuh dari tengkulak/bandar kepada petani ubi jalar. Hal tersebut membuat petani ubi jalar harus terus memasok hasil panen ubi jalar mereka ke tengkulak/bandar tertentu yang memberikan pinjaman tersebut hingga hutangnya terlunasi. Sehingga mayoritas responden petani ubi jalar hanya menjadi price taker.

Hal tersebut mengindikasikan bahwa kondisi saat ini ternyata tidak berbeda jauh dengan saat awal responden petani ubi jalar memulai usahatani ubi jalarnya. Tujuan pasar yang tidak banyak berubah hingga saat ini juga membuat sistem penentuan harga tidak banyak berubah. Dengan sumber permodalan petani dari awal usahatani yang sudah dapat dikatakan cukup mandiri, maka sejak awal petani cenderung memilih pasar dengan sistem pembayaran yang tunai.

\section{Analisis Pendapatan Usahatani Ubi Jalar di Keca- matan Arjasari, Kabupaten Bandung}

Pendapatan usahatani meruakan penghasilan yang diterima oleh petani dari kegiatan usahataninya. Pendapatan usahatani ubijalar adalah merupakan selisih antara penerimaan dengan biaya produksi usahatani ubi jalar.

Komponen biaya usahatani terbesar adalah biaya tenaga kerja luar keluarga yaitu sebesar $45 \%$ dari total biaya. Penggunaan tenaga kerja luar keluarga karena tenaga kerja yang berasal dari dalam keluarga tidak mencukupi atau tidak tersedia. Kurangnya tenaga kerja 
dalam keluarga karena isteri mengutamakan mengurus rumahtangga dan anak-anak masih sekolah atau bekerja di tempat lain. Usahatani ubi jalar banyak menggunakan tenaga kerja laki-laki karena jenis pekerjaan berat dalam pengolahan lahan, penanaman dan pemanenan. Penelitian Situmorang (2013) dan Nursan (2015) menemukan bahwa tenaga kerja merupakan komponen biaya usahatani terbesar pada usahatani jagung. Sedangkan Leovita, dkk. (2015) menemukan bahwa tenaga kerja merupakan komponen biaya usahatani terbesar pada usahatani ubi jalar.

Tabel 8. Pendapatan Usahatani Ubi Jalar per Ha per Musim Tanam di Kecamatan Arjasari tahun 2018

\begin{tabular}{lr}
\hline \multicolumn{1}{c}{ Uraian } & \multicolumn{1}{c}{ Nilai } \\
\hline Produktivitas $(\mathrm{Kg} / \mathrm{Ha})$ & 11.218 \\
Harga Ubi Jalar $(\mathrm{Rp} / \mathrm{Kg})$ & 2.775 \\
Penerimaan Usahatani $(\mathrm{Rp} / \mathrm{Ha})$ & 31.129 .950 \\
Biaya Produksi Usahatani $(\mathrm{Rp} / \mathrm{Ha})$ & 13.860 .960 \\
Pendapatan Usahatani $(\mathrm{Rp} / \mathrm{Ha})$ & 17.268 .990 \\
BEP Volume $(\mathrm{Kg})$ & 4.635 \\
BEP Harga $(\mathrm{Kg})$ & 1.146 \\
R/C atas Biaya Total & 2,2 \\
\hline
\end{tabular}

Sumber: Data Primer 2018

Biaya input terbesar lainnya adalah pembelian bibit ubi jalar sebesar $25 \%$ dari biaya total. Hal ini karena harga bibit rata-rata tergolong mahal yaitu Rp 110,- per bibit dan penggunaan bibit sembarang yang tidak sesuai anjuran. Penggunaan bibit ubi jalar di tempat penelitian sekitar 60.000 bibit per hektar. Sesuai anjuran Dinas Pertanian, dalam satu hektar efektif ditanami $80 \%$ dengan jarak tanam $75 \mathrm{~cm}$ x $30 \mathrm{~cm}$ dan keperluan bibit sekitar 35.555 bibit. Namun umumnya petani di Kecamatan Arjasari menggunakan jarak tanam kurang dari yang seharusnya, sehingga kebutuhan akan bibit tinggi dan mengakibatkan biaya untuk bibit dan tenaga kerja untuk penanaman juga besar. Berdasarkan perhitungan R/C (penerimaan dibagi biaya) usahatani ubi jalar memiliki nilai besar yaitu 2,2 artinya setiap Rp 1.000,- biaya yang dikeluarkan petani dalam kegiatan produksi akan mendapatkan penerimaan sebesar Rp. 2.200,-. Nilai R/C lebih dari satu artinya usahatani ubi jalar layak untuk dilakukan. Kelayakan usahatani tidak hanya ditentukan aspek ekonomi semata, tetapi juga aspek sosial yaitu kompetensi petani, budaya (kebiasaan) petani, lingkungan (iklim), dan regulasi (kebijakan) pemerintah yang mendukung usahatani ui jalar.

\section{SIMPULAN}

Karakteristik individu petani ubi jalar di Kecamatan Arjasari meliputi rata-ratapetani berusia 51 tahun, menjadikan usahatani ubi jalar sebagai pekerjaan utama untuk memenuhi kebutuhan keluarga, berpendidikan terakhir SD (Sekolah Dasar), memiliki rata-rata pengalaman usahatani ubi jalar selama 18 tahun, memiliki lahan ubi jalar dengan status milik pribadi yakni 0,11-0,5 Ha, dan tidak memiliki kebun/lahan ubi jalar lain yang digarap ataupun disewa. Profil usahatani ubi jalar menunjukkan mayoritas petani menanam ubi jalar varietas kuningan putih (AC Putih) dan varietas ubi ungu. Varietas kuningan putih ini merupakan varietas lokal dan paling banyak dibudidayakan oleh petani di Kecamatan Arjasari. Kegiatan pemupukan ubi jalar biasanya hanya dilakukan sekali saja yaitu pada saat tanaman berusia sekitar 2 bulan dengan sistem pembukaan tanah. Petani mampu menghasilkan produksi ubi jalar sebanyak 250-300 kg $/ 100 \mathrm{~m}^{2}$. Tujuan pasar petani responden yakni bandar yang berada di sekitar lokasi tempat tinggal atau lahan ubi jalar dengan menggunakan sistem pembayaran secara tunai/cash maupun tebasan. Kegiatan pascapanen seperti penyortiran dilakukan oleh petani dan bandar bersamaan saat kegiatan jual-beli berlangsung.

\section{UCAPAN TERIMA KASIH}

Ucapan terima kami sampaikan kepada Universitas Padjadjaran yang telah memberikan dana penelitian melalui Hibah Internal Unpad (HIU), Skema Riset Kompetensi Dosen Unpad (RKDU) tahun anggaran 2018.

\section{DAFTAR PUSTAKA}

Anderson, D.R., Sweeney, D.J., Williams, T.A., Camm, J.D. \& Cochran, J.J. (2016). Statistics for business \& economics. Nelson Education.

Asmarantaka, R.W. (2017). Efisiensi dan ProspektifUsaha Tani Ubi Jalar (Studi Kasus Desa Petir, Dramaga, Jawa Barat, Indonesia). Jurnal Pangan, 26, (1), 29-36. DOI: https://doi.org/10.33964/jp.v26i1.348

Burri, B.J.(2011). Evaluating Sweet Potato as an Intervention Food to Prevent Vitamin A Deficiency. Compr. Rev. Food Sci. Food Saf. 10, (2), 118-130. DOI: https:// doi.org/10.1111/j.1541-4337.2010.00146.x

El Sheikha, A.F. \& Ray, R.C. (2017). Potential impacts of bioprocessing of sweet potato. Critical reviews in food science and nutrition, 57, (3), 455-471. DOI: https://doi.org/10.1080/10408398.2014.960909

Ishida, H., Suzuno, H., Sugiyama, N., Innami, S., Tadokoro, T. \& Maekawa, A. (2000). Nutritive Evaluation on Chemical Components of Leaves, Stalks and Stems of Sweet Potatoes (Ipomoea batatas Poir ). Food Chemistry. 68, (3), 359-367. https://doi. org/10.1016/S0308-8146(99)00206-X 
Kementerian Pertanian. (2018). Aneka Umbi Unggul: Ubi kayu-ubi jalar-talas. (http://repository.pertanian. go.id/handle/123456789/5451, diakses tgl 3 Maret 2019)

Leovita, A., Asmarantaka, R.W. \& Daryanto, H.K.S. (2015). Analisis Pendapatan dan Efisiensi Teknis Usahatani Ubijalar di Kecamatan Ampek Angkek, Kabupaten Agam, Provinsi Sumatera Barat. Jurnal Agribisnis Indonesia, 3, (1), 11-24. DOI: https://doi.org/10.29244/jai.2019.7.1.63-78

Manrique, I., \& Roca, W. (2007). Potential of Sweetpotato (Ipomoea batatas) Biodiversity as a Functional Food in the Tropics. In Workshop "Functional Foods and Medicinal Products Developments from Amazonian Crops" - EULAFF - EMBRAPA WORKSHOP Rio de Janeiro, Brazil, Dec. 3-5, 2007. CIP, Rio de Jenero, Brazil.

Mujiburrahmad, M., \& Maryamsari, I. (2014). Karakteristik Petani Dan Hubungannya Dengan Kompetensi Petani Lahan Sempit (Kasus: Di Desa Sinar Sari Kecamatan Dramaga Kab. Bogor Jawa Barat). Jurnal Agrisep, 15, (2), 58-74. DOI: https:// doi.org/10.31186/agrisep.18.2.235-248

Nedunchezhiyan, M., Byju, G. \& Jata, S.K. (2012). Sweet potato agronomy. Fruit, Vegetable and Sereal Science and Biotechnology, 6, (1), 1-10.
Nugroho, A. \& Widaryanto, E. (2017). Yield response of ten varieties of sweet potato (Ipomoea batatas L.) cultivated on dryland in rainy season. Journal of Degraded and Mining Lands Management, 4, (4), 919-929. DOI: https://doi.org/10.15243/ jdmlm.2017.044.919

Nursan, M. Efisiensi dan Daya Saing Usahatani Jagung Pada Lahan Kering dan Sawah di Kabupaten Sumbawa. [Tesis]. Bogor (ID): Sekolah Pascasarjana, Institut Pertanian Bogor.

Rachmat, M. (2016). Kesempatan kerja dan prospek ketenagakerjaan dalam pengembangan tebu di Jawa. Jurnal Forum Penelitian Agro Ekonomi, 9, (2-1), 30-39. DOI: http://dx.doi.org/10.21082/fae. v9n2-1.1992.30-39

Rusdiana, S. \& Maesya, A. (2017). Pertumbuhan ekonomi dan kebutuhan pangan di Indonesia. Jurnal Agriekonomika, 6, (1), 12-25. DOI: https://doi. org/10.21107/agriekonomika.v6i1.1795

Situmorang, H. (2013). Tingkat Efisiensi Ekonomi dan Daya Saing Usahatani Jagung di Kabupaten Dairi Provinsi Sumatera Utara. [Tesis]. Bogor (ID): Sekolah Pascasarjana, Institut Pertanian Bogor.

Soekartawi. (1995). Analisis Usahatani. Jakarta. (ID): Universitas Indonesia Press.

Zuraida, N., \& Supriati, Y. (2011). Usahatani Ubi Jalar sebagai Bahan Pangan Alternatif dan Diversifikasi Sumber Karbohidrat. Buletin Agrobio, 4, (1), 13-23. 